\title{
ASSOCIATION BETWEEN INHERITED THROMBOPHILIA IN PREGNANCY AND MICRONUCLEUS FREQUENCY IN PERIPHERAL BLOOD LYMPHOCYTES
}

\author{
Šošić GM ${ }^{1, *}$, Jović $\mathrm{N}^{2,5}$, Rakić $\mathrm{B}^{3}$, Dimitrijević $\mathrm{A}^{2,4}$, Varjačić $\mathrm{M}^{2,5}$
}

\begin{abstract}
*Corresponding Author: Gordana M. Šošić, B.Sc., Department of Cytogenetic Diagnosis, Obstetrics and Gynecology Clinic, Clinical Center "Kragujevac," 30 Zmaj Jovina Street, 3400 Kragujevac, Serbia. Tel: +381-63-835-66-24.

Fax:+381-34-37-00-73. Email: gordana.sosic.2011.02@gmail.com
\end{abstract}

\begin{abstract}
The aim of this study was to determine possible predictors of an increased frequency of micronucleus (MN) and the impact of thrombophilia on the chromosomal instability in peripheral blood lymphocytes (PBL) of pregnant women in their first trimester. This study was designed as a case-control study on 74 pregnant women. It was performed in the gestational age of 11 to 14 weeks, when blood samples were collected and incubated for 72 hours. The individual MN frequency in PBL was measured by cytokinesis-block micronucleus (CBMN) assay. Women were grouped in control group [ $\leq 4 \mathrm{MN} / 1000$ binucleated (BN) cells] and case group ( $>4 \mathrm{MN} / 1000 \mathrm{BN}$ cells). Potential mutagenic effects of exogenous/endogenous factors in pregnant women were analyzed. By analyzing the given results, it can be concluded that pregnant women with thrombophilia have 26.69-times more chance of having a frequency of $>4 \mathrm{MN} / 1000 \mathrm{BN}$ than pregnant women with no thrombophilia. Our research was primarily aimed at showing that the presence of thrombophilia was a statistically important predictor of an increased $\mathrm{MN}$ frequency in pregnant women and it can predict about one-third of the total variance in $\mathrm{MN}$ frequency in the studied population.

Keywords: Lymphocytes; Micronuclei; Pregnant women; Thrombophilia.
\end{abstract}

\footnotetext{
$\overline{{ }^{1} \text { Department of Cytogenetic Diagnosis, Obstetrics and Gynecology }}$ Clinic, Clinical Center "Kragujevac," Kragujevac, Serbia

2 Faculty of Medical Sciences, University of Kragujevac, Kragujevac, Serbia

${ }^{3}$ Department of Medical Survey, Institute of Occupational Health "Dr Dragomir Karajović," Belgrade, Serbia

${ }^{4}$ Department of Fertility Control, Obstetrics and Gynecology Clinic, Clinical Center "Kragujevac," Kragujevac, Serbia

${ }^{5}$ Department of Pathology of Pregnancy, Obstetrics and Gynecology Clinic, Clinical Center “Kragujevac," Kragujevac, Serbia
}

\section{INTRODUCTION}

During their lifetime, humans are exposed to exogenous and endogenous agents who may react with cellular biomolecules, especially with the DNA molecule and induce changes in the genetic material that can lead to genomic instability [1]. Micronucleus (MN) is a cytoplasmic small nucleus containing particles of chromatin material that is not incorporated into the nucleus of one of the daughter cells during division. Under the influence of clastogenic and aneugenic agents, micronuclei (MNi) are produced and they may come from acentric chromatid/ chromosome fragments or whole chromatids/chromosomes [1,2]. In health biomonitoring, cytokinesis-block MN (CBMN) assay is used to measure basal and induced chromosomal damage in the peripheral blood lymphocytes (PBL) [2-3] and MN frequency represents a quantitative indicator of structural and/or numerical chromosomal aberrations [4-6].

The basal (spontaneous) MN frequency in PBL is a measure of accumulated chromosomal aberrations occurring during the lifetime of circulating lymphocytes [7]. The level of basal MN frequency is determined by the contribution of genetic damage to the DNA that comes from environmental factors and endogenous factors (genetic and non genetic determinants) and the elimination of DNA damage (that is determined by individual variations in genes involved in DNA repair) [8]. The induced MN frequency is the result of exposure to possible different chemical, physical and biological mutagens and carcinogens of natural or artificial origin [2-4]. Gender, age, body weight, diet, life habits, presence of inflammation, ionizing radiation and the use of certain medicines, affect the increase of the MN frequency $[9,10]$. Higher MN frequency in PBL is seen in persons with carcinoma [11], neurodegenerative diseases [12], cardiovascular diseases $[13,14]$, autoimmune diseases [15], diabetes mellitus type 
2 (T2DM) [16] and in persons with Down syndrome and their parents [17]. For example, elevated MN frequency is positively correlated with the occurrence and the severity of coronary artery disease (CAD) $[16,18]$. It has been reported that the TT genotype in the methylenetetrahydrofolate reductase (MTHFR) C677T gene variant is significantly associated with the higher MN in CAD patients [5]. Genomic stability is essential for normal fetal growth and development [19] and previous studies have indicated the potential role of elevated $\mathrm{MN}$ in predicting pregnancy complications in humans [20].

Thrombophilia presents a hereditary and acquired hemostatic system disorder in which there is a tendency towards thrombosis. During pregnancy, hypercoagulability and hypofibrinolysis are present, which, together with inherited and acquired thrombophilia conditions, can lead to pregnancy complications [21]. A previous study has shown the effectiveness of the treatment with low-molecular-weight heparin (LMWH) on pregnancy outcomes in women with thrombophilia [22].

There have been no clinical studies conducted to assess the mutagenic potential of thrombophilia and complications associated with this condition during pregnancy. The aim of this study was to evaluate known risk factors, to determine possible predictors of an increased frequency of MN in PBL and the impact of thrombophilia on the chromosomal instability in pregnant women in the first trimester.

\section{MATERIALS AND METHODS}

Experimental Design and Subjects. The study was designed as a case-control study involving pregnant women admitted to the Department of Obstetrics and Gynecology of our Clinic in 2015. Having been informed, the pregnant women signed the agreement to take part in the study approved by the local Ethics Council (No. 01-12294) and filled in the questionnaire containing basic medical history necessary for research in the field of cytogenetics as well as for evaluations of exposure history. The study included 74 pregnant women of gestational age 11 to 14 weeks. The excluding criteria were the following: exposure to environmental and professional mutagens, exposure to X-ray medical procedures, using oral hormonal contraceptives in the previous year, the presence of other chronic diseases (except thrombophilia), the intake of antibiotics and anti-epileptics during pregnancy and using narcotics. Blood samples from the pregnant women with thrombophilia were taken before starting anticoagulant therapy with LMWH. The pregnant women were grouped according to the value of the $\mathrm{MN}$ in the control group $[\leq 4 \mathrm{MN} / 1000$ binucleated $(\mathrm{BN})$ cells] and the group of cases $(>4 \mathrm{MN} / 1000 \mathrm{BN}$ cells $)$.

Blood samples were drawn following the usual procedure and they were kept refrigerated for 24 hours. All the heparinized blood $(0.5 \mathrm{~mL})$ was cultured in duplicate in $5 \mathrm{~mL}$ complete medium (Gibco ${ }^{\circ}$ PB-MAX ${ }^{\mathrm{TM}}$ Karyotyping Medium; Invitrogen, Carlsbad, CA, USA) and incubated at $37^{\circ} \mathrm{C}$.

Cytokinesis-Block Micronucleus Assay. The CBMN assay was performed 44 hours after the cultivation began by adding Cytohalazin B ${ }^{\text {TM }}$ (Sigma-Aldrich, St. Louis, MO, USA) to the cultures in final concentration of $4 \mu \mathrm{g} / \mathrm{mL}$. After continual incubation of cell cultures for an additional 28 hours, the cells were treated with cold $\left(4^{\circ} \mathrm{C}\right)$ hypotonic $(0.56 \% \mathrm{KC} 1)$ solution and fixed three times with fresh Carnoy's fixative composed of methanol and glacial acetic acid (ZORKA Pharma-HEMIJA d.o.o, Šabac, Serbia) in a ratio of $3: 1$. The cell material was dripped onto dry and cold microscope slides and the dried slides were colored by $2.0 \%$ Giemsa stain solution (BioGnost ${ }^{\circledR}$ ) d.o.o, Zagreb, Croatia). Micronucleus frequencies were determined by scoring $1000 \mathrm{BN}$ cells per person, according to the criteria previously defined by Fenech et al. [23].

Statistical Data Processing. The entire statistical analysis was performed using the Statistical Package for Social Sciences (SPSS) version 22.0 for Windows software (IBM, Armonk, NY, USA). The results are shown in the tables. To present the results of the categorical variables, absolute values and their percentage distribution were used. The experimental results of continuous numerical values were presented as mean \pm standard deviation (SD) values. The $\chi^{2}$ test was applied for determining the differences in the frequency of categorical variables. The significance of the differences between the means of studied variables was tested by the Mann-Whitney and Kruskal-Wallis tests. Binary logistic regression analysis was applied to identify risk factors and to assess the impact of independent variables on the case and control groups. The results are presented as odds ratio (OR) with $95 \%$ confidence interval (95\% CI) and the $p$ value. Univariate analysis was applied to all the parameters, while multivariate analysis was used for statistically significant parameters. A $p$ value of $<0.05$ was considered significant.

\section{RESULTS}

The examined women included in the study $(n=74)$ were 21 to 39 years old, median 30 years old. The average age of women included in this study was $29.93 \pm 4.51$. Within this group, the first trimester combined aneuploidy screening test was applied to 62 women below the age 
of 35. Pregnancy associated plasma protein-A (PAPPA), free $\beta$ human chorionic gonadotropin (fbHCG) and fetal nuchal translucency (NT) were compared between healthy pregnant women $(n=33)$ and pregnant women with thrombophilia $(n=29)$. The PAPP-A $(\mathrm{mLU} / \mathrm{L})$ values were significantly higher $(p=0.028)$, whereas fbHCG (IU/L) levels were lower and fetal NT (mm) measurements were higher in women with thrombophilia, but these differences were not statistically significant.

The average MN frequency in the examined population of pregnant women was $6.09 \pm 4.78 \mathrm{MN} / 1000 \mathrm{BN}$. The obtained median of $4.50 \mathrm{MN} / 1000 \mathrm{BN}$ for the whole population was used as a limit for forming examination case and control groups $(\leq 4 \mathrm{MN} / 1000 \mathrm{BN}$ cells and $>4 \mathrm{MN} / 1000$ $\mathrm{BN}$ cells). In this model, we investigated the influence of the predictor variables on the outcome.

The average age in the control group was not significantly different from the one in the case group $(29.49 \pm 4.58$ vs. $30.38 \pm 4.46 ; t=0.848, p=0.399)$. In the case group, there were more cases of thrombophilia $(p=0.000)$ and miscarriages $(p=0.002)$, an increased number of miscarriages $(p=0.010)$ and of pregnancies $(p=0.023)$ (Table 1$)$.
Table 2 shows the exogenous risk factors and risk factors related to family anamnesis. It can be observed that most of the pregnant women did not smoke $(81.1 \%)$, or use alcohol (90.5\%) during pregnancy. Pregnant women who consumed alcohol did it irregularly. It was determined that most of them did not have relatives with malignant diseases, venous thromboembolism and CADs or T2DM (Table 2). In the group of pregnant women with frequency $>4 \mathrm{MN} / 1000 \mathrm{BN}$, there were more women who used alcohol compared to the control group (18.9 vs. $0.0 \% ; p=0.017)$. In the group with higher MN frequency, we also noticed statistically significant increased alcohol consumption compared to the control group with lower MN frequency ( $p=0.021$ ) (Table 2).

The prediction of all the studied risk factors in our model for the percentage of pregnant women with frequency $>4 \mathrm{MN} / 1000 \mathrm{BN}$ was determined by univariate binary logistic regression analysis (Table 3). Using the goodness-of-fit test, it showed how well our model (a set of predictor variables shown in Tables 1 and 2) predicted results. It was shown that with a given set of predictor variables our model anticipated the results of the univariate binary logistic regression analysis $(p<0.005$, with an

Table 1. Examined risk factors related to personal anamnesis (age, thrombophilia, previous miscarriages and body mass index.)

\begin{tabular}{|c|c|c|c|c|c|c|c|}
\hline \multicolumn{2}{|l|}{ Examined Risk Factors } & \multirow{3}{*}{$\begin{array}{l}\text { Total } \\
(\%)\end{array}$} & \multicolumn{4}{|c|}{ Pregnant Women } & \multirow{3}{*}{$\begin{array}{c}\chi^{2} \\
(p \text { value }) \\
\end{array}$} \\
\hline & & & \multicolumn{2}{|c|}{$\begin{array}{c}\text { Control } \\
\leq 4 \mathrm{MN} / 1000 \mathrm{BN}\end{array}$} & \multicolumn{2}{|c|}{$\begin{array}{c}\text { Cases } \\
>4 \mathrm{MN} / 1000 \mathrm{BN}\end{array}$} & \\
\hline & & & $n$ & $\%$ & $n$ & $\%$ & \\
\hline Thrombophilia presence & $\begin{array}{l}\text { no } \\
\text { yes }\end{array}$ & $\begin{array}{l}50.0 \\
50.0\end{array}$ & $\begin{array}{r}31 \\
6 \\
\end{array}$ & $\begin{array}{l}83.8 \\
16.2\end{array}$ & $\begin{array}{r}6 \\
31 \\
\end{array}$ & $\begin{array}{l}16.2 \\
83.8\end{array}$ & $0.000^{\mathrm{a}}$ \\
\hline Year categories & $\begin{array}{l}20-29 \\
30-39 \\
\end{array}$ & $\begin{array}{l}50.0 \\
50.0\end{array}$ & $\begin{array}{l}19 \\
18 \\
\end{array}$ & $\begin{array}{l}51.4 \\
48.6 \\
\end{array}$ & $\begin{array}{l}18 \\
19\end{array}$ & $\begin{array}{l}48.6 \\
51.4\end{array}$ & 1.000 \\
\hline Previous miscarriages & $\begin{array}{l}\text { no } \\
\text { yes }\end{array}$ & $\begin{array}{l}51.4 \\
48.6 \\
\end{array}$ & $\begin{array}{l}26 \\
11 \\
\end{array}$ & $\begin{array}{l}70.3 \\
29.7 \\
\end{array}$ & $\begin{array}{l}12 \\
25 \\
\end{array}$ & $\begin{array}{l}32.4 \\
67.6 \\
\end{array}$ & $0.002^{\mathrm{a}}$ \\
\hline Miscarriage categories & $\begin{array}{l}0+1 \\
\geq 2\end{array}$ & $\begin{array}{l}86.5 \\
13.5 \\
\end{array}$ & $\begin{array}{r}34 \\
3 \\
\end{array}$ & $\begin{array}{r}91.9 \\
8.1 \\
\end{array}$ & $\begin{array}{r}30 \\
7 \\
\end{array}$ & $\begin{array}{l}81.1 \\
18.9 \\
\end{array}$ & 0.308 \\
\hline Number of miscarriages & $\begin{array}{r}0 \\
1 \\
2 \\
\geq 3 \\
\end{array}$ & $\begin{array}{r}51.4 \\
33.8 \\
12.2 \\
2.7 \\
\end{array}$ & $\begin{array}{r}26 \\
8 \\
3 \\
0 \\
\end{array}$ & $\begin{array}{r}70.3 \\
21.6 \\
8.1 \\
0.0 \\
\end{array}$ & $\begin{array}{r}12 \\
17 \\
6 \\
2 \\
\end{array}$ & $\begin{array}{r}32.4 \\
45.9 \\
16.2 \\
5.4 \\
\end{array}$ & $0.010^{\mathrm{a}}$ \\
\hline FMU & $\begin{array}{l}\text { no } \\
\text { yes }\end{array}$ & $\begin{array}{r}94.6 \\
5.4\end{array}$ & $\begin{array}{r}37 \\
0 \\
\end{array}$ & $\begin{array}{r}100.0 \\
0.0 \\
\end{array}$ & $\begin{array}{r}33 \\
4 \\
\end{array}$ & $\begin{array}{l}89.2 \\
10.8 \\
\end{array}$ & 0.123 \\
\hline Number of FMU & $\begin{array}{l}0 \\
1 \\
\end{array}$ & $\begin{array}{r}94.6 \\
5.4 \\
\end{array}$ & $\begin{array}{r}37 \\
0 \\
\end{array}$ & $\begin{array}{r}100.0 \\
0.0 \\
\end{array}$ & $\begin{array}{r}33 \\
4 \\
\end{array}$ & $\begin{array}{l}89.2 \\
10.8\end{array}$ & 0.123 \\
\hline Pregnancy order & $\begin{array}{r}1 \\
2 \\
3 \\
\geq 4\end{array}$ & $\begin{array}{l}31.1 \\
29.7 \\
25.7 \\
13.5 \\
\end{array}$ & $\begin{array}{r}17 \\
10 \\
8 \\
2 \\
\end{array}$ & $\begin{array}{r}45.9 \\
21.6 \\
5.4 \\
20.0 \\
\end{array}$ & $\begin{array}{r}6 \\
12 \\
11 \\
8 \\
\end{array}$ & $\begin{array}{l}16.2 \\
32.4 \\
29.7 \\
21.6\end{array}$ & $0.023^{\mathrm{a}}$ \\
\hline BMI & $\begin{array}{l}<24.99 \mathrm{~kg} / \mathrm{m}^{2} \\
\geq 24.99 \mathrm{~kg} / \mathrm{m}^{2}\end{array}$ & $\begin{array}{l}74.3 \\
25.7\end{array}$ & $\begin{array}{r}29 \\
8\end{array}$ & $\begin{array}{c}78.4 \\
8(21.6)\end{array}$ & $\begin{array}{l}26 \\
11\end{array}$ & $\begin{array}{c}70.3 \\
11(29.7)\end{array}$ & 0.595 \\
\hline
\end{tabular}

FMU: fetus mortus in utero; BMI: body mass index.

a Statistically significant $(p<0.05)$. 
Table 2. Examined risk factors related to exogenous agents exposure during the present pregnancy as well as a potential risk factors in the families.

\begin{tabular}{|c|c|c|c|c|c|c|c|}
\hline \multicolumn{2}{|c|}{ Examined Risk Factors } & \multirow{3}{*}{$\begin{array}{c}\begin{array}{c}\text { Total } \\
(\%)\end{array} \\
\\
81.1 \\
18.9 \\
\end{array}$} & \multicolumn{2}{|c|}{$\begin{array}{c}\text { Control } \\
\leq 4 \mathrm{MN} / 1000 \mathrm{BN} \\
\end{array}$} & \multicolumn{2}{|c|}{$\begin{array}{c}\text { Cases } \\
>4 \mathrm{MN} / 1000 \mathrm{BN} \\
\end{array}$} & \multirow{3}{*}{$\begin{array}{c}\begin{array}{c}\chi^{2} \\
(p \text { value })\end{array} \\
\\
0.138\end{array}$} \\
\hline & & & $n$ & $\%$ & $n$ & $\%$ & \\
\hline Smoking & $\begin{array}{l}\text { no } \\
\text { yes }\end{array}$ & & $\begin{array}{r}33 \\
4\end{array}$ & $\begin{array}{l}89.2 \\
10.8\end{array}$ & $\begin{array}{l}27 \\
10\end{array}$ & $\begin{array}{l}73.0 \\
27.0\end{array}$ & \\
\hline Number of cigarettes & $\begin{array}{c}0 \\
1-9 \\
10-19\end{array}$ & $\begin{array}{r}81.1 \\
16.2 \\
2.7 \\
\end{array}$ & $\begin{array}{r}33 \\
4 \\
0\end{array}$ & $\begin{array}{r}89.2 \\
10.8 \\
0.0 \\
\end{array}$ & $\begin{array}{r}27 \\
8 \\
2\end{array}$ & $\begin{array}{r}73.0 \\
21.6 \\
5.4 \\
\end{array}$ & 0.140 \\
\hline Alcohol use & $\begin{array}{l}\text { no } \\
\text { yes }\end{array}$ & $\begin{array}{r}90.5 \\
9.5 \\
\end{array}$ & $\begin{array}{r}37 \\
0 \\
\end{array}$ & $\begin{array}{c}100.0 \\
0.0 \\
\end{array}$ & $\begin{array}{r}30 \\
7 \\
\end{array}$ & $\begin{array}{l}81.1 \\
18.9 \\
\end{array}$ & $0.017^{\mathrm{a}}$ \\
\hline Amount of alcohol & $\begin{array}{c}0 \mathrm{~mL} \\
1-100 \mathrm{~mL} \\
>100 \mathrm{~mL}\end{array}$ & $\begin{array}{r}90.5 \\
8.1 \\
1.4\end{array}$ & $\begin{array}{r}37 \\
0 \\
0\end{array}$ & $\begin{array}{r}100.0 \\
0.0 \\
0.0\end{array}$ & $\begin{array}{r}30 \\
6 \\
1\end{array}$ & $\begin{array}{r}81.1 \\
16.2 \\
2.7\end{array}$ & $0.021^{\mathrm{a}}$ \\
\hline Carcinoma in family & $\begin{array}{c}\text { no } \\
\text { yes } \\
\end{array}$ & $\begin{array}{l}79.7 \\
20.3 \\
\end{array}$ & $\begin{array}{r}32 \\
5 \\
\end{array}$ & $\begin{array}{l}86.5 \\
13.5 \\
\end{array}$ & $\begin{array}{l}27 \\
10 \\
\end{array}$ & $\begin{array}{l}73.0 \\
10.0\end{array}$ & 0.247 \\
\hline CAD in family & $\begin{array}{c}\text { no } \\
\text { yes }\end{array}$ & $\begin{array}{l}74.3 \\
25.7\end{array}$ & $\begin{array}{l}27 \\
10\end{array}$ & $\begin{array}{l}73.0 \\
27.0\end{array}$ & $\begin{array}{r}28 \\
9\end{array}$ & $\begin{array}{l}75.7 \\
24.3\end{array}$ & 1.000 \\
\hline Thrombosis in family & $\begin{array}{l}\text { no } \\
\text { yes }\end{array}$ & $\begin{array}{l}79.7 \\
20.3 \\
\end{array}$ & $\begin{array}{r}32 \\
5 \\
\end{array}$ & $\begin{array}{l}86.5 \\
13.5 \\
\end{array}$ & $\begin{array}{l}27 \\
10 \\
\end{array}$ & $\begin{array}{l}73.0 \\
27.0 \\
\end{array}$ & 0.247 \\
\hline T2DM in family & $\begin{array}{l}\text { no } \\
\text { yes }\end{array}$ & $\begin{array}{l}87.8 \\
12.2\end{array}$ & $\begin{array}{r}33 \\
4\end{array}$ & $\begin{array}{l}89.2 \\
10.8\end{array}$ & $\begin{array}{r}32 \\
5\end{array}$ & $\begin{array}{l}86.5 \\
13.5\end{array}$ & 1.000 \\
\hline
\end{tabular}

CAD: coronary artery disease; T2DM: diabetes mellitus type 2.

a Statistically significant $(p<0.05)$.

indicator $\chi^{2}$ from 64,356,589 for 19 degrees of freedom). The Hosmer and Lemeshow test supported the claim that the model was good $(p=0.980>0.05)$. The given set of variables in our models explained between $58.1 \%$ (Cox $\&$ Snell R Square) and 77.5\% (Nagelkerke R Square) of variance in $\mathrm{MN}$ frequency.

Significant risk factors in the univariate model were thrombophilia $(p=0.000)$, miscarriages $(p=0.002)$, the number of miscarriages $(p=0.004)$ and the number of pregnancies $(p=0.005)$. The significant risk factors from the univariate model were included in the multivariate logistic regression analysis, which showed that hereditary or combined thrombophilia during pregnancy $(\mathrm{OR}=76.06 ; 95 \% \mathrm{CI}$ $=7.97-724.39 ; p=0.000)$ had a significant partial influence on the frequency of $>4 \mathrm{MN} / 1000 \mathrm{BN}$ occurrence (Table 3 ).

In the examined group, the pregnant women who consumed alcohol had frequencies of $>4 \mathrm{MN} / 1000 \mathrm{BN}$. The analysis showed that there was a lack of statistically significant difference in the mean values of the MN frequency between the groups of women who did not use alcohol and those who consumed alcohol during pregnancy $(5.87 \pm 4.18 v s .7 .36 \pm 7.50 ; p=0.939)$. There was also no statistically significant difference between the mean MN frequency in the groups concerning an increased intake of alcohol $(p=0.246)$. These results are consistent with the univariate analysis in which alcohol consumption and an increased alcohol intake do not represent a significant risk factor for the increased frequency of $\mathrm{MN}$.

By analyzing the given results it can be concluded that pregnant women with thrombophilia are 26.69-times more likely to have the frequency of $>4 \mathrm{MN} / 1000 \mathrm{BN}$ than pregnant women without thrombophilia. Pregnant women who had previous miscarriages or recurrent miscarriages and a higher number of pregnancies, are 4.92, 2.85 and 2.05 more likely to have the frequency of $>4 \mathrm{MN} / 1000 \mathrm{BN}$ than pregnant women with no present risk factors (Table 3 ).

\section{DISCUSSION}

Micronucleus presence is an indicator of genomic instability and accumulated damages that appeared during the lymphocyte's life cycle and can be detected in vitro [3]. Every process that affects the DNA damage and/or chromosomes and spindle apparatus directly or indirectly increases the $\mathrm{MN}$ frequency. The most important processes are oxidative processes in the cell [2], gene polymorphisms and mutations that affect genomic instability [3].

Micronuclei are present in humans, as well as spontaneously formed in the range of $0-12 \mathrm{MN} / 1000 \mathrm{BN}$ cells [7]. In our study, the individual variation of the $\mathrm{MN}$ frequencies in the group of pregnant women was within a wide range of $\mathrm{MN}$ frequency variations (1-25 MN/1000BN). Wide varia- 
Table 3. Univariate and multivariate logistic regression analyses of examined factors influence on frequency presence $>4 \mathrm{MN} / 1000 \mathrm{BN}$ in pregnant women.

\begin{tabular}{|l|c|c|c|c|}
\hline \multirow{2}{*}{ Examined Risk Factors } & \multicolumn{2}{|c|}{ Univariate Analysis } & \multicolumn{2}{c|}{ Multivariate Analysis } \\
\hline & OR $(95 \% \mathrm{CI})$ & $p$ Value & OR (95\% CI) & $p$ Value \\
\hline Thrombophilia & $26.694(7.754-91.901)$ & $0.000^{\mathrm{a}}$ & $76.058(7.986-724.391)$ & $0.000^{\mathrm{a}}$ \\
\hline Age & $1.046(0.944-1.159)$ & 0.394 & - & - \\
\hline Year categories & $1.114(0.448-2.773)$ & 0.816 & - & - \\
\hline Previous miscarriages & $4.924(1.838-13.190)$ & $0.002^{\mathrm{a}}$ & $0.256(0.014-4600)$ & 0.355 \\
\hline Miscarriage categories & $2.644(0.627-11.149)$ & 0.184 & - & - \\
\hline Number of miscarriages & $2.852(1.400-5.815)$ & $0.004^{\mathrm{a}}$ & $0.486(0.080-2.941)$ & 0.432 \\
\hline FMU & $1811289975.000(0.00-/)$ & 0.999 & - & - \\
\hline Number of FMU & $1811289975.000(0.00-/)$ & 0.999 & - & - \\
\hline Pregnancy order & $2.049(1.244-3.376)$ & $0.005^{\mathrm{a}}$ & $2.355(0.792-7.008)$ & 0.124 \\
\hline BMI & $1.534(0.535-4.398)$ & 0.426 & - & - \\
\hline Smoking & $3.056(0.861-10.839)$ & 0.084 & - & - \\
\hline Number of cigarettes per day & $2.999(0.940-9.569)$ & 0.063 & - & - \\
\hline Alcohol & $1,239(0.343-4.480)$ & 0.744 & & - \\
\hline Alcohol amount & $79899842.300(0.00-/)$ & 0.998 & - & - \\
\hline Relatives with carcinoma & $2.370(0.722-7.787)$ & 0.155 & - & - \\
\hline Relatives with CAD & $0.868(0.305-2.466)$ & 0.790 & - & - \\
\hline Relatives with thrombosis & $0.422(0.128-1.386)$ & 0.155 & - & - \\
\hline Relatives with diabetes & $1.289(0.317-5.237)$ & 0.723 & & - \\
\hline OR: & - & - & - \\
\hline
\end{tabular}

OR: odds ratio; 95\% CI: 95\% confidence interval; FMU: fetus mortus in utero; BMI: body mass index; CAD: coronary artery disease.

a Statistically significant.

tions of the $\mathrm{MN}$ frequency in the same group may be the result of different factors that influence chromosomal damage.

Kopjar et al. [3] reported mean frequency of $6.9 \pm$ $3.32 \mathrm{MN} / 1000 \mathrm{BN}$ cells in their study performed on healthy male and female subjects aged 20 to 61 in Croatia. The authors concluded that due to the differences in the organization of the research and the size of the population examined, the mean MN frequency was often higher or lower than the one determined in their research [3]. Our research has shown that the mean $\mathrm{MN}$ frequency in the studied population of pregnant women aged 20 to 33 is $6.09 \pm 4.78 \mathrm{MN} / 1000 \mathrm{BN}$ cells.

The results of the previous studies have shown that chromosomal aberrations could be found in the karyotype of 3.0-6.0\% of couples with recurrent miscarriages [24]. Fenech [20] wrote about MN frequency increase as one of the factors that could be connected with recurrent miscarriages, and Furness et al. [19] showed that in the high risk group [patients who had recurrent pregnancy loss (RPL), preeclamsia/eclampsia, intrauterine growth retardation (IUGR), placental abruption or preterm delivery] there was a statistically higher $\mathrm{MN}$ frequency comparing to low risk group. Toljic et al. [25] showed that in gestational diabetes
(GDM) and pregnancy-induced hypertension (PIH), there were elevated levels of oxidative stress, as well as damage to DNA and chromosomal aberration, which could be detected owing to elevated values of $\mathrm{MNi}$ in PBL of pregnant women.

Upon the performed examination, we deduced that the case group $(>4 \mathrm{MN} / 1000 \mathrm{BN})$ contained more statistically significant previous miscarriages and a higher number of miscarriages. The results presented in this study show that previous miscarriages and number of miscarriages are separate independent variables and represent significant predictors in the case group ( $>4 \mathrm{MN} / 1000 \mathrm{BN})$, while the multivariate analysis allocated only thrombophilia as an important predictor of an increased $\mathrm{MN}$ frequency in the case group ( $>4 \mathrm{MN} / 1000 \mathrm{BN})$.

Studies analyzing the effects of smoking on MN frequency have shown contradictory findings. Studies performed by Kopjar et al. [3] as well as the one conducted by Nefic et al. [26] showed that smokers have statistically significant higher MN frequency than non smokers. In most of the research studies, the link between smoking and MN frequency was not found. Fenech et al. [27] concluded that radical $\mathrm{MN}$ frequency increase can be found only in 
smokers who smoke more than 30 cigarettes a day and who are not professionally exposed to genotoxic agents. In our study, the maximal number of cigarettes was between 1 and 9 and this study was in accordance with some of the previous findings that showed no link between smoking status and an increased MN frequency.

Alcohol is a proven teratogenic agent that influences normal embryo and fetal development and it is implicated in the pathogenesis of the fetal alcohol syndrome. It is not known if any amount of alcohol is safe in pregnancy, but there are speculations that even a small amount of alcohol may harm the fetus. It is well-known that ethanol can easily cross the feto-placental barrier in both directions and concentrations in fetal and maternal circulation thus equalize [28]. Studies on animal models have shown that ethanol may cause disorders on epigenetic level and that it may also disturb the coordinated process of cellular differentiation [29].

Alcohol toxicity can be seen not only as a direct effect of the ethanol, but also as an indirect effect through its metabolic products and reactive oxygen species (ROS) that appear during alcohol biotransformation [30]. Studies on animal models have shown that alcohol may induce higher ROS production, cause oxidative stress and react with proteins, lipid and DNA causing their damage or complete degradation [31]. Different studies have confirmed the genotoxic effect of ethanol by various cytogenetic and molecular tests $[32,33]$. In the study by Santovito et al. [34], significant differences in $\mathrm{MN}$ frequency between alcoholics and controls were not found, but they did find significant differences in frequency of sister chromatid exchanges (SCEs) and chromosome aberrations (CAs). The results of the studies by Benassi-Evans and Fenech [35] support the hypothesis that chronic exposure to alcohol induces formation of $\mathrm{MN}$ in two human $\mathrm{B}$ lymphoblastoid cell lines: WIL2-NS and GM13705.

We have shown that in the group of pregnant women with frequency of $>4 \mathrm{MN} / 1000 \mathrm{BN}$ there were significantly more women who consumed alcohol and the amount of alcohol consumed by the pregnant women was higher, but we did not find that these variables represented significant predictors of an increased MN frequency in the group of cases $(>4 \mathrm{MN} / 1000 \mathrm{BN})$. A statistically significant difference in the mean values of the MN frequency in women who consumed and did not consume alcohol during pregnancy was not found. This can be explained by the fact that the minority of women in our study consumed alcohol $(<10.0 \%)$ and no pregnant women chronically consumed alcohol.

During pregnancy hypercoagulability and hypofibrinolysis are present and together with inherited and acquired thrombophilia disorders they can lead to early complications of pregnancy (RPL) and late complications of pregnancy [PE, IUGR, placental abruption, premature birth and intrauterine fetal death (IUFD)] [24]. Prothrombophilic genetic variants Factor V Leiden and Prothrombin A20210G were significantly associated with a higher prevalence of RPL [24,36]. Šsšic et al. [37] found that in the group of women with inherited thrombophilia from Šumadija District, Serbia, previous miscarriages were most commonly noticed in double owners of gene variants plasminogen activator inhibitor-1 (PAI-1) 5G/4G and MTHFR, C677T.

Karsli et al. [38] found that there was an impact of inherited thrombophilia on the first trimester combined aneuploidy screening test parameters. They determined that PAPP-A levels were significantly higher, whereas fbHCG levels and fetal NT measurements were lower in women with inherited thrombophilia. In a similar study, carried out by C1kman et al. [39], the effect of inherited thrombophilia on second trimester combined aneuploidy screening test markers was investigated. They found that unconjugated estriol multiple of median (MoM) levels were significantly lower in women with inherited thrombophilia [39]. In our study, the results of the first trimester combined aneuploidy screening test were consistent with previous research of the PAPP-A levels.

Micronucleus forming in human cells is connected to many medical conditions. Pristov et al. [21] came up with the result that in pregnant women with thrombophilia, placental tissue is exposed to $\mathrm{H}_{2} \mathrm{O}_{2}$-mediated oxidative stress, which can originate from the mother's blood and the endothelium. The occurrence of $\mathrm{H}_{2} \mathrm{O}_{2}$ can be initiated by prothrombotic state present in mother, indicating a potential relation between a pregnancy complicated with thrombophilia and oxidative stress [21].

In our study, thrombophilia in pregnancy has a significant partial contribution to the occurrence of frequencies $>4 \mathrm{MN} / 1000 \mathrm{BN}$. Pregnant women with thrombophilia are 26.69-times more likely to have a frequency of $>4 \mathrm{MN} /$ $1000 \mathrm{BN}$ compared to pregnant women without thrombophilia. In the population of pregnant women, thrombophilia accounts for around one-third of variance in MN frequency.

\section{CONCLUSIONS}

It can be concluded that the frequency of micronuclei $>4 \mathrm{MN} / 1000 \mathrm{BN}$ depends on the presence of thrombophilia, previous miscarriages, the number of miscarriages and the number of pregnancies. The presence of thrombophilia in pregnancy in the study group is the most important pre- 
dictor variable of increased $\mathrm{MN}$ frequency. Based on the current knowledge, we hypothesize that the DNA damage, measured by the increase in frequency of $\mathrm{MN}$, probably occurs as a result of oxidative stress initiated by prothrombotic condition in the mother's blood.

\section{ACKNOWLEDGMENTS}

This study was financed according to the contract of realization of scientific research project "Micronuclei frequency in peripheral blood lymphocytes in pregnant women with thrombophilia" [number JP 02/15] from the basic Research Programme of the Faculty of Medical Sciences in Kragujevac, Serbia for 2015 [number 05-10599].

Declaration of Interest. The authors report no conflicts of interest. The authors alone are responsible for the content and writing of this article.

\section{REFERENCES}

1. Veerachari U, Venkatesh S, Yadav A, Narayanappa R. Biomonitoring genetic instability in normal healthy population using a simple cytogenetic marker - micronucleus test. Int Multidiscip Res J. 2011; 1/2: 01-09.

2. Šššić GM, Varjačić M. Uticaj fizičke aktivnosti na stepen hromozomskih aberacija. TIMS Acta. 2015; 9(1): 49-61.

3. Kopjar N, Kasuba V, Milić M, Rozgaj R, Zeljezić $\mathrm{D}$, Gajski G, et al. Normal and cut-off values of the cytokinesis-block micronucleus assay on peripheral blood lymphocytes in the Croatian general population. Arh Hig Rada Toksikol. 2010; 61(2): 219-234.

4. Fenech M, Kirsch-Volders M, Natarajan AT, Surralles J, Crott JW, Parry J, et al. Molecular mechanisms of micronucleus, nucleoplasmic bridge and nuclear bud formation in mammalian and human cells. Mutagenesis. 2011; 26(1): 125-132.

5. Luzhna L, Kathiria P, Kovalchuk O. Micronuclei in genotoxicity assessment: From genetics to epigenetics and beyond. Front Genet. 2013; 4: 131.

6. Fenech M. Cytokinesis-block micronucleus cytome assay. Nat Protoc. 2007; 2(5): 1084-1104.

7. Heddle JA, Fenech M, Hayashi M, MacGregor JT. Reflections on the development of micronucleus assays. Mutagenesis. 2011; 26(1): 3-10.

8. Surowy H, Rinckleb A, Luedeke M, Stuber M, Wecker A, Varga D, et al. Heritability of baseline and induced micronucleus frequencies. Mutagenesis. 2011; 26(1): 111-117.

9. Fenech M, Bonassi S. The effect of age, gender, diet and lifestyle on DNA damage measured using micronucleus frequency in human peripheral blood lymphocytes. Mutagenesis. 2011; 26(1): 43-49.

10. Ferraz GA, Costa Neto AdeO, Cerqueira En deMM, Meireles JRC. Effects of age on the frequency of micronuclei and degenerative nuclear abnormalities. Rev Bras Geriatr Gerontol. 2016; 19(4): 627-634.

11. Milosević-Djordjević O, Grujicić D, Vasković Z, Marinković D. High micronucleus frequency in peripheral blood lymphocytes of untreated cancer patients irrespective of gender, smoking and cancer sites. Tohoku J Exp Med. 2010; 220(2): 115-120.

12. Petrozzi L, Lucetti C, Scarpato R, Gambaccini G, Trippi $\mathrm{F}$, Bernardini S, et al. Cytogenetic alterations in lymphocytes of Alzheimer's disease and Parkinson's disease patients. Neurol Sci. 2002; 23(Suppl 2): S97-S98.

13. Scarpato R, Verola C, Fabiani B, Bianchi V, Saggese G, Federico G. Nuclear damage in peripheral lymphocytes of obese and overweight Italian children as evaluated by the-H2AX focus assay and micronucleus test. FASEB J. 2011; 25(2): 685-693.

14. Bhat MA, Mahajan N, Gandhi G. DNA and chromosomal damage in coronary artery disease patients. EXCLI J. 2013; 12: 872-884.

15. Torres-Bugarín O, Macriz Romero N, Ramos Ibarra ML, Flores-García A, Valdez Aburto P, Zavala-Cerna MG. Genotoxic effect in autoimmune diseases evaluated by the micronucleus test assay: Our experience and literature review. Biomed Res Int. 2015; 2015: 194031.

16. Andreassi MG, Barale R, Iozzo P, Picano E. The association of micronucleus frequency with obesity, diabetes and cardiovascular disease. Mutagenesis. 2011; 26(1): 77-83.

17. Silva-Grecco RL, Navarro GC, Cruz RM, Balarin MA. Micronucleated lymphocytes in parents of Down syndrome children. Braz J Med Biol Res. 2012; 45(7): 573-577.

18. Holland N, Bolognesi C, Kirsch-Volders M, Bonassi $\mathrm{S}$, Zeiger E, Knasmueller S, et al. The micronucleus assay in human buccal cells as a tool for biomonitoring DNA damage: The HUMN project perspective on current status and knowledge gaps. Mutat Res. 2008; 659(1-2): 93-108

19. Furness DL, Dekker GA, Hague WM, Khong TY, Fenech MF. Increased lymphocyte micronucleus fre- 
quency in early pregnancy is associated prospectively with pre-eclampsia and/or intrauterine growth restriction. Mutagenesis. 2010; 25(5): 489-498.

20. Fenech M. Micronuclei and their association with sperm abnormalities, infertility, pregnancy loss, preeclampsia and intra-uterine growth restriction in humans. Mutagenesis. 2011; 26(1): 63-67.

21. Pristov JB, Spasojevic I, Mikovic Ž, Mandic V, Cerovic N, Spasic M. Antioxidative defense enzymes in placenta protect placenta and fetus in inherited thrombophilia from hydrogen peroxide. Oxid Med Cell Longev. 2009; 2(1): 14-18.

22. Aracic N, Roje D, Drmic Hofman I, Capkun V, Stefanovic V. Low molecular weight heparin treatment and impact of inherited thrombophilia type in pregnancies with previous adverse outcome. J Matern Fetal Neonatal Med. 2015; 28(3): 306-310.

23. Fenech M, Chang WP, Kirsch-Volders M, Holland N, Bonassi S, Zeiger E; HUman MicronNucleus project. HUMN project: Detailed description of the scoring criteria for the cytokinesis-block micronucleus assay using isolated human lymphocyte cultures. Mutat Res. 2003; 534(1-2): 65-75.

24. Turki RF, Assidi M, Banni HA, Zahed HA, Karim S, Schulten HJ, et al. Associations of recurrent miscarriages with chromosomal abnormalities, thrombophilia allelic polymorphisms and/or consanguinity in Saudi Arabia. BMC Med Genet. 2016; 17(Suppl 1): $15-23$.

25. Toljic M, Egic A, Munjas J, Karadzov Orlic N, Milovanovic Z, Radenkovic A, et al. Increased oxidative stress and cytokinesis-block micronucleus cytome assay parameters in pregnant women with gestational diabetes mellitus and gestational arterial hypertension. Reprod Toxicol. 2017; 71: 55-62.

26. Nefic H, Musanovic J, Kurteshi K, Prutina E, Turcalov E. The effects of sex, age and cigarette smoking on micronucleus and degenerative nuclear alteration frequencies in human buccal cells of healthy Bosnian subjects. Saglik Bilim Derg. 2013; 3(3): 196-204.

27. Fenech M, Holland N, Zeiger E, Chang WP, Burgaz S, Thomas $\mathrm{P}$, et al. The HUMN and HUMNxL international collaboration projects on human micronucleus assays in lymphocytes and buccal cells - past, present and future. Mutagenesis. 2011; 26(1): 239-245.

28. Zergollen Lj i. suradnici, Malformacijski sindromi uzrokovani vanjski činiocima, Sambolek-Hrbić E. Medicinska Genetika, vol. 1. Zagreb, Hrvatska: Školska Knjiga. 1987: 150-159.
29. Veazey KJ, Carnahan MN, Muller D, Miranda RC, Golding MC. Alcohol-induced epigenetic alterations to developmentally crucial genes regulating neural stemness and differentiation. Alcohol Clin Exp Res. 2013; 37(7): 1111-1122.

30. Brocardo PS, Gil-Mohapel J, Christie BR. The role of oxidative stress in fetal alcohol spectrum disorders. Brain Res Rev. 2011; 67(1-2): 209-225.

31. Wu D, Cederbaum AI. Alcohol, oxidative stress, and free radical damage. Alcohol Res Health. 2003; 27(4): 277-284.

32. Singh S, Saini M, Yadav AS. Elevated frequencies of micronuclei and other nuclear anomalies in alcoholic subjects. J Entomol Zool Stud. 2015; 3(2): 243-245.

33. Demirhan O, Tastemir D. Cytogenetic effects of ethanol on chronic alcohol users. Alcohol Alcohol. 2008; 43(2): 127-136.

34. Santovito A, Cervella P, Delpero M. Evidence of genotoxicity in lymphocytes of non-smoking alcoholics. Mol Biol Rep. 2015; 42(1): 53-59.

35. Benassi-Evans B, Fenech M. Chronic alcohol exposure induces genome damage measured using the cytokinesis-block micronucleus cytome assay and aneuploidy in human B lymphoblastoid cell lines. Mutagenesis. 2011; 26(3): 421-429.

36. Kacprzak M, Chrzanowska M, Beata Skoczylas B, Moczulska H, Borowiec M, Sieroszewski P. Genetic causes of recurrent miscarriages. Ginekologia Polska. 2016; 87(10): 722-726.

37. Šošić GM, Sretenović S, Varjačić M. P-043: Genes polymorphism FV Leiden G1691A, FII G20210A, MTHFR C677T and PAI-1 5G/4G in patients with miscarriages and inherited thrombophilia - experience from our clinic. (Papers and Abstracts of the 7th International Symposium on Women's Health Issues in Thrombosis and Haemostastis, held on March 3-5, 2017 at Barcelona, Spain.) Thromb Res. 2017; 151(Suppl 1): S122-S123.

38. Karsli MF, Baser E, Seckin KD, Yeral MI, Togrul C, Ugur M. The impact of inherited thrombophilia on first trimester combined aneuploidy screening test parameters. J Matern Fetal Neonatal Med. 2014; 27(4): 346-349.

39. C1kman MS, Seckin KD, Karslı MF, Baser E, C1kman DI, Cicek MN. The effect of inherited thrombophilia on second trimester combined aneuploidy screening test markers. Arch Gynecol Obstet. 2015; 291(4): 787-790. 